\title{
Kamrai ritmuszavarok és hirtelen szívhalál. ESC-guideline összefoglaló
}

\author{
Salló Zoltán, Szegedi Nándor, Gellér László, Merkely Béla, Zima Endre
}

Semmelweis Egyetem, Városmajori Szív- és Érgyógyászati Klinika, Budapest

Levelezési cím: Dr. Zima Endre, e-mail: zima.endre@gmail.com

\begin{abstract}
Bevezetés
A kamrai tachycardia (VT) és kamrafibrilláció (VF) a hirtelen szívhalál egyik legföbb oka. Hátterében leggyakrabban iszkémiás szívbetegség vagy szívelégtelenség áll, azonban bizonyos esetekben az életveszélyes kamrai ritmuszavarok strukturálisan ép szívben is elöfordulhatnak. A gyógyszeres kezelés a legtöbb esetben nem mutatott kellő hatékonyságot, ezért az utóbbi évtizedekben a kombinált (gyógyszeres és eszközös) kezelések kerültek előtérbe. A választott terápiát a ritmuszavar jellege, valamint a hirtelen halál valószínüsége határozza meg.
\end{abstract}

\section{Definíció}

A kamrai ritmuszavarok a kamrákból (a His-köteg bifurkációja alatt) indulnak ki, és az esetek legnagyobb részében (95\%-ban) széles QRS-sel járnak. Az egyik leggyakoribb ritmuszavar a kamrai extrasystolia (VES), ilyenkor egy-egy, az alapritmus QRS-étől eltérő morfológiájú QRS látható az EKG-n. A VES-ek jelentkezhetnek kapcsolt formában is, ilyenkor 2-3 VES is követheti egymást. Amennyiben mindegyik VES azonos morfológiájú, monomorf kamrai extrasystoliáról, míg ha eltérő, polimorf kamrai extrasystoliáról beszélünk. Az előbbi általában egy gócból, az utóbbi - a morfológiáknak megfelelően - több gócból is eredhet. A három egymás utáni kamrai extrasystole a salve. Amennyiben ennél több extra kamrai akció követi egymást 100/perc feletti kamrai frekvenciával, de fél percnél rövidebb ideig, azt nem tartós kamrai tachycardiának (non-sustained VT, nsVT) nevezzük. A 100/percnél szaporább, fél percnél hosszabb kamrai ritmuszavar a tartós kamrai tachycardia (sustained VT). A tartós VT is lehet monomorf (ilyenkor mindegyik ütés QRS-morfológiája azonos), illetve polimorf (ilyenkor több QRS-morfológia is előfordul ugyanazon a VT-epizódon belül). Amennyiben a tartós VT több órán keresztül, orvosi beavatkozás (pl.: iv. adott antiaritmiás gyógyszerek, elektromos cardioversio [ECV]) ellenére is folyamatosan fennáll, azt incessant VT-nek nevezzük. Időnként az incessant VT jelentkezhet rövid VT-epizódokként (megfutások), amelyeket néhány supraventricularis ütés szakít meg. Elektromos viharnak nevezzük a 24 óra alatt bekövetkező legalább három különálló tartós VT- vagy VF-epizódot. Definíció szerint szintén ide tartozik továbbá a legalább 12 órán át folyamatosan fennáló incessant VT is. Az implantálható kardioverter-defibrillátorral (ICD) élő betegeknél elektromos viharként definiáljuk a 24 óra alatt több mint 3 adekvát ICD-terápiát igénylő, egymástól legalább 5 perc eltéréssel jelentkező ritmuszavar epizódokat.

A kamrai ritmuszavarok a hirtelen szívhalál legföbb okai. A hirtelen szívhalál klinikai szindróma, amely a legáltalánosabban elfogadott definíció szerint: szívbetegen vagy ismert szívbetegség nélküli személyen kardiogén ok miatt bekövetkező, váratlan, idő előtti, természetes halál, amelyet az öntudat hirtelen elvesztése előz meg és az akut tünetek kialakulásától számított egy órán belül következik be.

\section{Etiológia}

A VT általában strukturális szívbetegségben, az esetek nagy többségében korábbi szívinfarktuson átesett betegeknél alakulnak ki (,iszkémiás VT”), de egyre gyakrabban kerül elektrofiziológiai vizsgálatra és ablációra már ICD-vel élő, nem iszkémiás DCM-es beteg is VT miatt. Előfordulhatnak azonban ioncsatorna-betegségekben is (pl.: Brugada-szindrómia, hosszú/rövid QT-szindróma), valamint kiváltó okként szerepelhet elektroliteltérés, gyógyszerhatás vagy hypothermia is. Az esetek kb. 5\%-

A kézirat 2020. 05. 20-án érkezett a szerkesztőségbe, 2020. 06. 08-án került elfogadásra. 
ában kimutatható szívbetegség nincs a háttérben, ebben az esetben ún. idiopátiás VT-röl beszélünk. (Jobb vagy bal kiáramlási pálya tachycardia, fascicularis = Belhassen-típusú/veramapil szenzitív VT.)

A hirtelen szívhalálhoz vezető VF ugyancsak minimálisan $80 \%$-ban koronáriaszükülethez vagy elzáródáshoz köthető, további 10-15\%-ban egyéb strukturális szívbetegség áll a hátterében.

\section{Tünetek}

A tünetek széles skálán mozoghatnak. A VES-ek tünetmentesek is lehetnek, okozhatnak palpitációs panaszokat, angina pectorist, dyspnoét. Kamrai tachycardia kapcsán felléphet palpitációérzés, gyengeség, szédülés, dyspnoe, tüdőödéma, eszméletvesztés, kardiogén sokk. Ritkábban a beteg általános állapotától, illetve a ritmuszavar frekvenciájától függően akár tünetmentesség is előfordulhat. VF esetén keringésösszeomlás következik be.

\section{Diagnózis}

A korrekt diagnózis felállításához a ritmuszavar alatti EKG szükséges, amely lehetőleg 12 csatornás legyen, valamint tartalmazzon ún. ritmuscsíkot is. Alapvetően a széles QRS-tachycardiát kamrai eredetüként kell kezelni mindaddig, amíg ellenkezője biztosan be nem bizonyítható!

A VT EKG-kritériumai:

- V-A disszociáció,

- fúziós ütések,

- capture (befogott) ütések,

- extrém QRS-tengelyállás és QRS-szélesség (> $160 \mathrm{~ms}$ ),

- QRS-morfológia (Brugada-, illetve Vereckei-kritériumok).

A nyugalmi EKG szintén fontos, hiszen ezen lehetnek egyéb kórjelző eltérések, pl.: korábbi infarktust jelző Q-hullám, vagy adott kórképre jellegzetes eltérések (pl.: HCM, ARVC, Brugada-szindróma)

$A z$ első három EKG-kritérium igazolja a VT diagnózisát, a többi kritérium pedig valószínúsíti a diagnózist.

A beteg kivizsgálása során szükséges a további vizsgálatok elvégzése is:

- képalkotó vizsgálatok primer szívbetegség, falmozgászavar, esetleges iszkémiás etiológia, billentyübetegség tisztázása céljából: echokardiográfia, MRI, CT-angiográfia, vagy invazív koronarográfia.

- Amennyiben a beteg ICD-vel él, feltétlenül fontos ennek lekérdezése, az intrakardiális elektrogramok kiolvasása az ICD-memóriából.

- Ergometria (főleg VES-ek esetében), iszkémiaprokováció céljából.

- Elektrofiziológiai vizsgálat VT-indukció, illetve abláció céljából.

\section{Differenciáldiagnosztika}

Sok esetben nem könnyű a VT diagnózisának felállítása, mivel széles QRS-tachycardiát okozhatnak supraventricularis ritmuszavarok aberráns kamrai vezetéssel (korábban is meglévő vagy novum Tawara-szár-blokkal, vagy a magas pitvari frekvencia miatti funkcionális szárblokkal), vagy preexcitáció esetén (pl.: antidrom AVRT, vagy FBI-tachycardia). Az esetek kb. 5\%-ában a VT is járhat keskeny QRS-sel, ilyenkor a V-A disszociáció felfedezése, illetve az extrém jobb/bal tengelyállás segíthet a kamrai eredet felismerésében.

\section{Kórjóslat}

Strukturális szívbetegség hiányában a VES-ek és nsVT-k leggyakrabban benignusak. A strukturális szívbetegség kizárására a heg azonosítására alkalmas képalkotó eljárások (echokardiográfia, MRI) használata javasolt. A hirtelen szívhalálra hajlamosító legjelentősebb tényező a súlyos szisztolés szívelégtelenség (LVEF <30\%). A hirtelen szívhalál kockázatának további önálló meghatározói: hipertónia, diabetes mellitus, hypercholesterinaemia, dohányzás.

\section{Kezelés}

\section{Akut kezelés}

$\mathrm{Az}$ alapelv a ritmuszavar megszüntetése, a beteg kardiorespiratorikus stabilizálása, etiológia tisztázása és a rekurrencia megelőzése.

Amennyiben hemodinamikailag stabil, VT-s beteget látunk el, elsődlegesen antiaritmiás szert alkalmazunk, amennyiben instabil elsőként az ECV a választandó, rövid és óvatos narkózisban.

A kamrai ritmuszavarok akut kezelését az 1. táblázat foglalja össze.

Az incessant VT és az elektromos vihar ellátása különösen összetett feladatot jelent.

Elektromos vihar esetén az akut aritmiakezelés mellett célunk a beteg kardiorespiratorikus stabilizálása és párhuzamosan az etiológiai faktorok tisztázása és a reverzibilis okok kezelése (2. táblázat). A beteg invazív monitorozása elengedhetetlen, EKG, $\mathrm{SaO}_{2}, \mathrm{NIBP}$ mellett artériás invazív nyomásmérése indokolt, mindemellett vérgázanalízis is javasolt a rendszeres $\mathrm{PaO}_{2}$, $\mathrm{PCO}_{2}$, elektrolit és metabolikus faktorok monitorozása és korrekciója céljából. A beteg szedációja, béta-blokkoló, amiodaronkezelése, szükség esetén mély altatása és lélegeztetése szükséges. Az instabil beteg hemodinamikai támogatása iv. noradrenalinnal javasolt, míg pozitív inotróp szerek kerülendők. Indokolt esetben mechanikus keringéstámogatás is szóba jön (IABP, ECMO, VAD). Etiológia tisztázása képalkotókkal javasolt, amelyek felfedik a reverzibilis organikus okokat. Revaszkularizáció, organikus szívbetegségek (pl.: bil- 
1. TÁBLÁZAT. A kamrai ritmuszavarok akut kezelése

\begin{tabular}{|c|c|c|c|}
\hline & J avasolt & Megfontolható & Nem javasolt \\
\hline Monomorf tartós VT & $\begin{array}{l}\text { Hemodinamikai instabilitás esetén szedáció } \\
\text { és ECV } \\
\text { Hemodinamikai stabilitás esetén AAD }\end{array}$ & $\begin{array}{l}\text { iv. amiodaron, } \\
\text { iv. béta-blokkoló } \\
\text { iv. procainamid, } \\
\text { pacemakerrel való felülvezérlés }\end{array}$ & $\begin{array}{l}\text { Kalciumantagonisták, } \\
\text { adenozin }\end{array}$ \\
\hline Polimorf tartós VT & $\begin{array}{l}\text { Hemodinamikai instabilitás esetén szedáció } \\
\text { és ECV, ha stabil, akkor iv. béta-blokkoló \& } \\
\text { amiodaron }\end{array}$ & $\begin{array}{l}\text { iv. lidocain, ha miokardiális } \\
\text { infarktus akut szakához köthető } \\
\text { a VT }\end{array}$ & $\begin{array}{l}\text { Hosszú QT esetén } \\
\text { amiodaron }\end{array}$ \\
\hline $\begin{array}{l}\text { Torsades de Pointes } \\
\text { VT }\end{array}$ & $\begin{array}{l}\text { Elektroliteltérések rendezése, bradycardia } \\
\text { függő TdP esetén pacemakerimpl. Szerzett } \\
\text { hosszú QT gyakran gyógyszer-mellékhatás } \\
\text { következménye -> a Q-T szakaszt nyújtó } \\
\text { gyógyszerek elhagyása (sze. hemodialízissel } \\
\text { történő eltávolítása) szükséges }\end{array}$ & $\begin{array}{l}\text { iv. } \mathrm{MgSO}_{4} \text {, iv. isoproterenol (ha } \\
\text { pacemaker nem elérhető), } \\
\text { káliumszint } 4,5-5 \mathrm{mmol} / \mathrm{l} \text {-re } \\
\text { titrálása }\end{array}$ & $\begin{array}{l}\text { Hosszú QT esetén } \\
\text { amiodaron }\end{array}$ \\
\hline $\begin{array}{l}\text { Nem szünő } \\
\text { (incessant) VT }\end{array}$ & $\begin{array}{l}\text { Koronarográfia, mély szedáció + gépi } \\
\text { lélegeztetés, iv. béta-blokkolók, } \\
\text { akut katéterabláció }\end{array}$ & iv. amiodaron, katéterabláció & ICD-implantáció \\
\hline VF & $\begin{array}{l}\text { Defibrilláció, újraélesztés, iv. amiodaron, iv. } \\
\text { adrenalin, reverzibilis okok ellátása }\end{array}$ & $\begin{array}{l}\text { iv. béta-blokkoló, iv. lidocain, iv. } \\
\text { procainamid }\end{array}$ & \\
\hline
\end{tabular}

Rövidítések: VT: kamrai tachycardia, ECV: elektromos kardioverzió; ICD: implantálható kardioverter defibrillator, AAD: antiaritmiás gyógyszer

lentyübetegségek, kamrai aneurizma) szívelégtelenség maximális kezelése javasolt.

\begin{abstract}
Általános hosszú távú kezelés
Az akut ellátás után a feladat a háttérben álló alapbetegség kezelése (pl. koronária-revaszkularizáció), illetve a kamrai ritmuszavar ismételt előfordulásának megelőzése. Utóbbinál a standard terápia az ICD-implantáció. Az ICD-implantációra vonatkozó ajánlásokat a 3. táblázat foglalja össze. Az epizódok gyakoriságát csökkentő gyógyszerek a béta-blokkolók, illetve hatástalanság esetén az amiodaron. A visszatérés megelőzésének egyre nagyobb teret nyerő hatékony módszere a katéteres abláció. Az abláció során számos
\end{abstract}

\section{TÁBLÁZAT. Az elektromos vihar ellátásában alkalmazható terápiás lehetőségek \\ Intenzív osztályos ellátás \\ Eszköz (ICD) programozás}

Reverzibilis eltérések korrekciója (pl.: iszkémia, ionháztartási zavar, gyógyszerhatás)

Béta-blokkoló, antiaritmiás szerek (CAVE: polipragmázia!)

Katéteres abláció - endocardialis \pm epicardialis

Mechanikus keringéstámogatás (IABP, ECMO, VAD)

Neuraxiális moduláció (pl.: thoracalis epiduralis anesztézia, kardiális szimpatikus denerváció, ggl. stellatum blokád, renális denerváció)

\section{Egyéb antiaritmiás terápia}

Alternatív lehetőségek (pl.: transzkoronáriás etanolos abláció, sebészi abláció aneurysmectomia, sztereotaxiás besugárzás)

\section{Szívtranszplantáció}

Rövidítések: ICD: implantálható kardioverter defibrillátor; IABP: intra-aortikus ballon pumpa; ECMO: extracorporalis membrán oxigenátor; VAD: kamrai keringéstámogató eszköz stratégia alkalmazható (pl.: heghomogenizáció, kilépési pont ablációja, VT ishtmus régió ablációja), amely a VT típusától, valamint az operatőr jártasságától és a rendelkezésre álló technikától függ. A heg-reentry mechanizmusú VT-k esetén az akut siker ellenére a betegek 20-44\%-ában a ritmuszavar visszatérhet. Az idiopathiás, kiáramlási pálya-eredetű VES-ek, illetve VT-k esetén a pontszerú góc ablációja relatíve magas sikeraránnyal kivitelezhető (90-95\%).

\section{Speciális kezelés \\ Strukturális szívbetegség talaján kialakuló tartós VT \\ (heg-reentry VT) \\ Hosszú távú kezelés:}

- gyógyszeres kezelés: béta-blokkoló (ez az egyetlen mortalitást szignifikánsan csökkentő gyógyszercsoport VT esetén!), amiodaron, sotalol, mexiletin;

- ICD-implantáció.

Rádiófrekvenciás katéterabláció (RFCA): definitív terápiát jelenthet (4. táblázat).

Sikertelenség esetén kiegészítő terápiájaként felmerülhetnek egyéb modalitások úgy, mint a szimpatikus idegrendszeri denerváció, renális denerváció, ggl. stellatum blokád, lokális besugárzás, szívsebészeti beavatkozás (pl.: aneurysmectomia, szívtranszplantáció) is.

\section{Idiopathiás VT}

Az idiopathiás VT viszonylag ritkán (5\%-ban) előforduló entitás, az alábbiakban röviden jellemezzük az egyes típusait.

Kiáramlási pálya $(V O T=$ ventricular outflow tract) eredetü VT

- Idiopathiás jobb kamra kiáramlási pálya tachycardia (RVOT VT): 
3. TÁBLÁZAT. ICD-implantációra vonatkozó ajánlások (ESC 2015)
Ajánlás
ICD-implantáció javasolt dokumentált VF, vagy hemodinamikailag nem tolerált VT esetén

ICD-implantáció megfontolandó optimális gyógyszeres kezelés ellenére visszatérő sustained VT esetén, megtartott balkamra-funkció esetén (kivéve a miokardiális infarktus első 48 órájában)

VT/NF esetén, ha ICD nem elérhető vagy a beteg elutasítja, amiodaronkezelés megfontolható

Szubkután ICD-implantáció megfontolandó, ha pace-elésre várhatóan nincs szükség

Primer prevenciós célzattal ICD-implantáció javasolt LVEF $\leq 35 \%$ esetén, iszkémiás etiológia esetén (tehát posztinfarktusos betegben)

Primer prevenciós célzattal ICD-implantáció javasolt LVEF $\leq 35 \%$ esetén, noniszkémiás etiológia esetén

Röviditések: ICD = implantábilis cardioverter defibrillátor; VT = kamrai tachycardia; VF = kamrafibrilláció; LVEF = bal kamrai ejekciós frakció

\section{Ajánlás osztálya Evidenciaszint}

I

Ila

IIb $\quad$ C

Ila

I
A

C

C

C

A

B

\section{TÁBLÁZAT. Katéterablációra vonatkozó ajánlások (ESC 2015)}

\section{Ajánlás}

Abláció javasolt incessant $\mathrm{VT}$, illetve elektromos vihar esetén

Abláció javasolt strukturális szívbetegség hiánya esetén jelentkező RVOT-tachycardia, illetve idiopathiás bal kamrai tachycardia esetén

Abláció javasolt iszkémiás szívbetegség esetén, rekurrens VT-epizódok esetén

Abláció javasolt Tawara-reentry kamrai tachycardia esetén

Abláció megfontolandó iszkémiás szívbetegség esetén, az első tartós VT-epizódot követöen

Abláció megfontolandó ARVC esetén rekurrend VT-epizódok előfordulásakor

Abláció megfontolható noniszkémiás cardiomyopathiás betegnél jelentkező gyógyszerrefrakter kamrai tachycardia esetén

Abláció megfontolható Brugada-szindrómás betegnél rekurrens appropriate ICD-sokkok esetén

Ajánlás osztálya

Evidenciaszint

\begin{tabular}{|c|c|}
\hline I & B \\
\hline I & B \\
\hline I & B \\
\hline I & C \\
\hline Ila & B \\
\hline Ila & B \\
\hline Ilb & C \\
\hline
\end{tabular}

Ilb

C

Rövidítések: ICD = implantábilis cardioverter defibrillátor; VT = kamrai tachycardia; VF = kamrafibrilláció; LVEF = bal kamrai ejekciós frakció

Az idiopathiás VT vagy extrasystolia leggyakoribban a jobb kamrai kiáramlásból ered. Ez a ritmuszavar fokális eredetü, típusosan a pulmonalis billentyűk alatt a jobb kamrai kiáramlás septalis részén található a góc. Emiatt a QRS bal Tawaraszár-blokkos morfológiájú, inferior, jobbra deviáló tengelyállással és praecordialis elvezetésekben késői ( $\mathrm{V}_{3}$ után) tranzícióval. $\mathrm{A}$ ritmuszavar gyógyszeres kezelésében a béta-blokkolók, valamint időnként a propafenon és a kalciumcsatorna-blokkolók és a sotalol is hatékonyak lehetnek. Magas számban jelentkező VES-ek, nsVT-k vagy tartós kamrai tachycardiák esetén katéterabláció megfontolandó, különösen, ha a beteg számára panaszokat okoz.

- Idiopathiás bal kamra kiáramlási pálya tachycardia (LVOT VT):

Az LVOT VT és VES-ek EKG-képe hasonló a jobb kamraiakéhoz, de $V_{1}$-ben az R-hullám gyakran nagyobb, mint az $\mathrm{S}$, vagy széles r-hullám van jelen, valamint a praecordialis elvezetésekben a tranzíció $\mathrm{V}_{3}$-nál korábban jelenik meg. A ritmusza- var gyógyszeres kezelésében alkalmazhatók a fent már említett bétareceptor-blokkolók, sotalol, ritkábban propafenon. Itt is hangsúlyoznunk kell, hogy tartós ritmuszavar esetén katéterabláció lehet szükséges. A ritmuszavarok általában jó balkamra-funkció mellett alakulnak ki, ezért általában ICD-beültetés első körben sem az RVOT VT, sem az LVOT VT típusú ritmuszavaroknál nem javasolt.

\section{Idiopathiás bal kamrai tachycardia (ILVT)}

Az idiopathiás fascicularis bal kamrai tachycardia (Belhassen-tachycardia vagy verapamil-szenzitív tachycardia) egy fontos és nem ritka szívritmuszavar (az idiopathiás VT-k 10-15\%-a), specifikus EKG-jelekkel és terápiás lehetőségekkel. A kamrai tachycardia EKG-képe relatíve keskeny (100-140 ms) QRS-morfológiát mutat jobb Tawara-szár-blokk morfológiával. A QRS-tengelyállás attól függ, hogy melyik fasciculus része a reentry körnek. Baltengely-deviáció van jelen bal posterior fascicularis tachycardia, jobbtengely-deviáció pedig bal anterior fascicularis tachycardia esetén. Bal septalis fascicularis tachycardia együtt járhat 
normál tengelyállással is. A fascicularis tachycardiák általában strukturális szívbetegség nélkül alakulnak ki, verapamil kezelésre jól reagálnak. Néhány esetben intravénás adenozin is hatékony lehet a ritmuszavar terminálásában. A fascicularis tachycardiában szenvedő betegek nagy részében sinusritmusban és a kamrai tachycardia alatt is feltehetően a Purkinje-rost eredetű, a QRS-t megelőző preszisztolés vagy diasztolés potenciál regisztrálható. Ez a potenciál segíti az aritmia szubsztrát megtalálását, segíti a leghatékonyabb terápiát, a katéterablációt. A ritmuszavar azonnali felismerése és ablációs centrumba történő irányítása azért fontos, mert az abláció definitív terápiát jelenthet! $A z$ ICD-beültetés ezekben az esetekben első körben nem javasolt.

\section{Tawara-szár-reentry kamrai tachycardia}

A Tawara-szár-reentry a strukturális szívbetegségek (cardiomyopathiák és billentyübetegségek) kapcsán kialakuló kamrai tachycardiák közel 8\%-ában fordul elő. Általában a His-Purkinje-rendszer betegségével, valamint csökkent szisztolés balkamra-funkcióval jár együtt. A kamrai tachycardia QRS-e a bal Tawaraszár-blokkos sinusritmus alatti QRS-morfológiára hasonlít. A jobb Tawara-szár, esetenként a bal Tawaraszár vagy egyik fasciculis ablációja kuratív lehet, ezért az ICD-beültetés a strukturális szívbetegségben nem szenvedő páciensekben nem javasolt. Számos betegnél azonban az alapbetegség miatt kardiális reszinkronizációs terápia szükségessége is felmerül, amennyiben tünetes szívelégtelenség, csökkent balkamra-funkció is fennáll.

\section{Primer elektromos szívbetegségek}

Ebbe a csoportba tartoznak a veleszületett hosszú QT-szindróma (LQTS), az idiopathiás VT és VF, a katecholaminerg polimorf VT, valamint a Brugada-szindróma $(\mathrm{BrS})$.

- LQTS esetén jellemzően polimorf kamrai tachycardia jelentkezik, a tengelyállás csavarodása miatt ezt a ritmuszavart Torsade de Pointes-nek hívjuk. Normál QT-idő mellett igazolt genetikai eltérés esetén is javasolt béta-blokkoló adása. ICD beültetése szükséges bétareceptor-blokkoló kezelés mellett jelentkező syncope vagy kamrai tachycardia esetén.

- LQT2- vagy LQT3-mutáció esetén tünetmentes esetben is alkalmazandó bétareceptor-blokkoló és ICD beültetése. A hirtelen szívhalál rizikójával pozitívan korrelál a $\mathrm{QT}_{\mathrm{c}}$ időtartama. Az egyes altípusokra jellegzetes a malignus ritmuszavar jelentkezésének körülménye: LQT1-úszás, fizikai terhelés;
LQT2-hirtelen erős hanginger; LQT3-nyugalom, alvás.

- Katekolaminerg polimorf VT elsősorban terhelésre és pszichés stresszre jelentkezhet, amelynek kezelésére béta-blokkoló, illetve ICD-beültetés jön szóba.

- Brugada-szindrómában az EKG-n a $V_{1}-V_{3}$ elvezetésekben J-pont-eleváció jelentkezik JTSzB-hez hasonló képpel, jellegzetes „háztetőszerü” STelevációt eredményezve. Ilyen betegeknél syncope, illetve VT esetén ICD beültetése szükséges. BrS-hez társuló elektromos vihar esetén isoproterenol alkalmazandó. A ritmuszavar kezelésében a katéteres abláció is lehetséges. Rizikómeghatározás céljából ajmalin, flecainid, procainamid teszt, illetve elektrofiziológiai vizsgálat alkalmazható.

- Idiopathiás VF esetén sem strukturális, sem pedig a fent leírt elektromos szívbetegségek nem állnak a ritmuszavar hátterében. Kezelése béta-blokkolók alkalmazása és ICD implantációja.

\section{Nyilatkozat}

A szerzők kijelentik, hogy az összefoglaló közlemény megírásával kapcsolatban nem áll fenn velük szemben pénzügyi vagy egyéb lényeges összeütközés, összeférhetetlenségi ok, amely befolyásolhatja a közleményben bemutatott eredményeket, az abból levont következtetéseket vagy azok értelmezését.

\section{Irodalom}

1. Priori SG, Blomström-Lundqvist C, Mazzanti A, Blom N, Borggrefe M, Camm J, Elliott PM, Fitzsimons D, Hatala R, Hindricks G, Kirchhof P, Kjeldsen K, Kuck KH, Hernandez-Madrid A, Nikolaou N, Norekvål TM, Spaulding C, Van Veldhuisen DJ; Task Force per il Trattamento dei Pazienti con Aritmie Ventricolari e la Prevenzione della Morte Cardiaca Improvvisa della Società Europea di Cardiologia. [2015 ESC Guidelines for the management of patients with ventricular arrhythmias and the prevention of sudden cardiac Death. The Task Force for the Management of Patients with Ventricular Arrhythmias and the Prevention of Sudden Cardiac Death of the European Society of Cardiology]. G Ital Cardiol (Rome) 2016 Feb; 17(2): 108-70. DOI: 10.1714/2174.23496. Italian. PubMed PMID: 27029760 2. Zima E: Elektromos vihar, incessant kamrai arrhythmiák intenzív ellátása. pp 907-918. In: Fazekas T, Merkely B, Papp Gy, Tenczer J. (szerk.) Klinikai szívelektrofiziológia és aritmológia. Budapest: Akadémiai Kiadó; 2016. DOI: 10.1556/9789630597487

3. Salló Z, Szegedi N, Merkely B, Gellér L. 2018. "Az Elektromos Vihar Ellátása: A Katéteres Abláció Szerepe." CARDIOLOGIA HUNGARICA 2018; 48(4): 263-268. doi:10.26430/CHUNGARICA.2018.48.4.263 4. Dragos C, Tint D, Szegedi N, Sallo Z, Gellér L. (2019). Update in Electrical Storm Therapy. American Journal of Therapeutics 2019; 26: e257-e267. 10.1097/MJT.0000000000000918 